\title{
A Study of Emotional Intelligence of Primary Teachers in Relation to Gender, School Type \& Teaching Experience
}

\author{
Dr. Shashi Chaudhary ${ }^{1}$, Prof. Kavita Varma ${ }^{2}$ \\ ${ }^{1}$ Assistant Professor, Faculty of Education, GLA University, Mathura, Uttar Pradesh, India. \\ E-mail: shashi.chaudhary@gla.ac.in \\ ${ }^{2}$ Principal, Faculty of Education, GLA University, Mathura, Uttar Pradesh, India. \\ E-mail: kavita.varma@gla.ac.in
}

Article History: Received: 11 January 2021; Accepted: 27 February 2021; Published online: 5 April 2021

\begin{abstract}
In the present research study, emotional intelligence has been studied with reference to the gender, school type and teaching experience of primary teachers of Agra and Mathura district. In this study Gender taken as male\& female, School Type taken as government \& non-government and Teaching experience of teachers divided into four categories: first category (less than 5 years of teaching experience), second category (5-15 years of teaching experience), third category (16-25 years of teaching experience), fourth category (more than 25 years of teaching experience). A total of 800 teachers working in primary schools have been selected for sample through random method. Teachers Emotional Intelligence Inventory standardized tool made by Dr. Subhra Mangal, It consists of 100 items consisting four components each having 25 items. In overall result of the study there is no meaningful difference found in emotional intelligence of primary teachers regarding gender, School types and teaching experiences.
\end{abstract}

\section{Keywords: Emotional Intelligence, Primary Teachers, Gender.}

\section{Introduction}

Emotional intelligence helps a person to work more effectively in a collective manner. In general, emotional intelligence proves beneficial in every activity of life. According to Mayer \& Salovey, 1997-"Emotional intelligence is the ability to perceive emotions, to access and generate emotions so as to assist thought, to understand emotions and emotional knowledge, and to reflectively regulate emotions so as to promote emotional and intellectual growth. "Daniel Goleman stated that "Emotional intelligence is the ability of a person to recognize the emotions of himself and others, which can motivate us and helps us to practice our emotions well in ourselves and during our relationships."S. Hein defines "Emotional intelligence is the mental capacity with which we are born, which gives us sensitive sensitivity and emotional understanding of our abilities."

\section{Purpose of the Study}

To study the percentage level of emotional intelligence of primary teachers in relation to gender, school type and teaching experience.

\section{Objective of the Study}

To study the emotional intelligence of primary teachers in relation to gender, school type and teaching experience.

\section{Hypothesis of the Study}

There is no difference in between the emotional intelligence of primary teachers in relation to gender, school type and teaching experience.

\section{Methodology}

The present study is dealing with the investigation of emotional intelligence of primary school teachers in relation to gender, school type and teaching experience. The researcher has employed survey method. Teachers Emotional Intelligence Inventory standardized tool made by Dr. Subhra Mangal, It consists of 100 items. It consists four components each having 25 items. The participants were required to respond either yes or no. The random sampling method was used. It attempts to describe and interpret practices, processes, trends, effects, attitudes and beliefs etc. of the present phenomenon. Hence, this method has been found to be most suitable for present study. After collection of data result analysis was done by using percentage statistics method.

\section{Population and Sample of the Study}

All teachers working in the Primary schools of Mathura and Agra district of Uttar Pradesh constituted the population of the present study. A total of 800 teachers working in primary schools have been selected for sample through random sampling method. 


\section{Variables}

Dependent Variable -Gender, School Type \& Teaching Experience

Independent Variable - Emotional Intelligence

\section{Tools Used}

Teachers Emotional Intelligence Inventory standardized tool made by Dr. Subhra Mangal. It consists of 100 items. It consists four components each having 25 items. The participants were required to respond either yes or no. This inventory measuring emotional intelligence on 4 areas namely: a) Intra-personal awareness b) Interpersonal awareness c) Intra-personal management d) Inter-personal management.

\section{Result Analysis}

The level of emotional intelligence of teachers is presented in the given below table in the percentage in relation to gender, school type and teaching experience.

Table 1. Levels of Emotional Intelligence of Primary Teachers: In Relation to Gender, School Type and Teaching Experience

\begin{tabular}{|c|c|c|c|c|c|c|c|c|c|c|c|c|c|c|c|c|}
\hline \multirow{4}{*}{$\begin{array}{c}\text { Levels of } \\
\text { Emotional } \\
\text { Intelligence }\end{array}$} & \multicolumn{16}{|c|}{ Teacher number and percentage } \\
\hline & \multicolumn{4}{|c|}{ Gender } & \multicolumn{4}{|c|}{ School Type } & \multicolumn{8}{|c|}{ Teaching Experience } \\
\hline & \multicolumn{2}{|c|}{$\begin{array}{c}\text { Female } \\
N=400\end{array}$} & \multicolumn{2}{|c|}{$\begin{array}{c}\text { Male } \\
\mathrm{N}=400\end{array}$} & \multicolumn{2}{|c|}{$\begin{array}{l}\text { Gover. } \\
N=400\end{array}$} & \multicolumn{2}{|c|}{$\begin{array}{l}\text { Non- } \\
\text { Gov. } \\
\text { N=400 }\end{array}$} & \multicolumn{2}{|c|}{$\begin{array}{c}\text { Less } \\
\text { than } 5 \\
N=252\end{array}$} & \multicolumn{2}{|c|}{$\begin{array}{c}5-15 \\
\text { year } \\
\mathrm{N}=433\end{array}$} & \multicolumn{2}{|c|}{$\begin{array}{c}16-25 \\
\text { year } \\
\mathbf{N}=101\end{array}$} & \multicolumn{2}{|c|}{$\begin{array}{c}\text { More } \\
\text { than } 25 \\
N=14\end{array}$} \\
\hline & $\mathrm{N}$ & $\%$ & $\mathrm{~N}$ & $\%$ & $\mathrm{~N}$ & $\%$ & $\mathrm{~N}$ & $\%$ & $\mathrm{~N}$ & $\%$ & $\mathrm{~N}$ & $\%$ & $\mathrm{~N}$ & $\%$ & $\mathrm{~N}$ & $\%$ \\
\hline Very High & 02 & - & 01 & - & 03 & 01 & - & - & 01 & - & 02 & - & - & - & - & - \\
\hline High & 05 & 01 & 10 & 02 & 11 & 03 & 04 & 01 & 05 & 02 & 10 & 02 & - & - & - & - \\
\hline Average & 17 & 04 & 29 & 07 & 25 & 06 & 21 & 05 & 11 & 04 & 28 & 07 & 07 & 07 & - & - \\
\hline Below Ave. & 66 & 17 & 158 & 40 & 105 & 26 & 119 & 30 & 69 & 28 & 117 & 27 & 34 & 34 & 04 & 29 \\
\hline Low & 310 & 78 & 202 & 51 & 256 & 64 & 256 & 64 & 166 & 66 & 276 & 64 & 60 & 59 & 10 & 71 \\
\hline
\end{tabular}

\section{Percentage of Teachers at Different Levels of Emotional Intelligence in relation to Gender}

Table 1 shows that $1 \%$ and $4 \%$ female teachers were found at high and average levels of emotional intelligence respectively, $17 \%$ female teachers were found at below average level and78\% found at low level while the percentage of female teachers at very high level of emotional intelligence is negligible. Similarly, $2 \%$ and $7 \%$ male teachers were found at high and average levels of emotional intelligence respectively, $40 \%$ and $51 \%$ male teachers were found at below average and low levels respectively, while the percentage of male teachers at very high level is negligible.

Thus, it is visible that at very high level of emotional intelligence, the percentage of female and male teachers is equally negligible and even at high and average levels of emotional intelligence, the percentage of female and male teachers is $1 \%$ and $2 \%$, $0 \mathrm{r} 4 \%$ and $7 \%$ respectively which is very less. There is a significant difference in the percentage of female and male teachers at below average and low levels of emotional intelligence, but also the highest teacher percentage ( $78 \%$ female and $51 \%$ male) is found at low level of emotional intelligence.

\section{Percentage of Teachers at Different Levels of Emotional Intelligence in relation to School Type}

Table 1 show that government teachers were found to be $1 \%, 3 \%, 6 \%$ respectively at very high, high and average levels of emotional intelligence, $26 \%$ percent at below average level, while $64 \%$ percent of government teachers were found at low level. Non-government teachers were found to be $1 \%$ and $5 \%$ respectively at high and average levels of emotional intelligence, $30 \%$ and $64 \%$ respectively at the below average and low levels, while the percentage of non-government teachers at very high level is negligible.

Thus, it is visible that the percentage of government and non-government teachers at very high and high levels of emotional intelligence is almost negligible (1\% and negligible) respectively and the percentage of government and non-government teachers even at the average level of emotional intelligence $6 \%$ and $5 \%$ respectively, which is very low. The percentage of government and non-government teachers at the below average and low levels is much higher as well as the highest teacher percentage has been found at low level of emotional intelligence (64\% government and 64\% non-government)

Percentage of Teachers at Different Levels of Emotional Intelligence in Relation to Teaching Experience It is known from Table 1 that at high and average levels of emotional intelligence $2 \%$ and $4 \%$ teachers were found respectively of the first category of teaching experience (less than 5 years), 28\% and 66\% teachers were 
found at below average and low levels respectively, while the percentage of teachers at high level of emotional intelligence is negligible. Second category of teaching experience (5-15 years) $2 \%$ and $7 \%$ teachers were found at high and average levels of emotional intelligence respectively, 27\% and 64\% at below average and low levels respectively, while the percentage of teachers at very high level is negligible. In the third category of teaching experience (16 to 25 years) 7\%, 34\% and 59\% teachers were found at average, below average and low levels of emotional intelligence respectively, while the percentage of teachers at very high and high level is negligible. In fourth category of teaching experience (more than 25 years) $29 \%$ and $71 \%$ teachers were found at below average and low levels of emotional intelligence respectively, while the percentage of teachers at very high, high and average levels is negligible. Thus it is visible that at very high and high levels of emotional intelligence, the percentage of teachers of all categories of teaching experience is negligible and the percentage of first, second and third categories of teaching experience teachers at the average level of emotional intelligence is $4 \%, 7 \%$ and $7 \%$ respectively which is very low. Generally, the percentage of teachers of all the categories of teaching experience is much higher at below average and low levels of emotional intelligence and The highest teacher percentage (66\% first category, $64 \%$ second category, $59 \%$ third category and $71 \%$ fourth category) is found at low level of emotional intelligence. In this way the level of emotional intelligence of less than 5 years and more than 25 years of teaching experience teachers was found very low.

Therefore, the hypothesis presented is that "the emotional intelligence of primary teachers differs in relation to gender, school type and teaching experience". Emotional intelligence has been found in teachers at very high, high, average, below average and low levels.

\section{Conclusion}

There is a difference in emotional intelligence of primary teachers. Most teachers are found at low level of emotional intelligence (78\% to $71 \%$ ). A lower level of emotional intelligence was found in $17 \%$ to $40 \%$ teachers. The percentage of teachers at high and average levels of emotional intelligence is very low, at the very high level, the percentage of teachers is usually $1 \%$ or negligible.

In the context of gender, meaningful difference was not found in the emotional intelligence of primary teachers. Emotional intelligence of female and male teachers was found to be the same. In the context of school type, meaningful difference was not found in the emotional intelligence of primary teachers. Emotional intelligence of government and non-government teachers was found to be the same.

In the context of teaching experience, meaningful difference was not found in the emotional intelligence of primary teachers. The emotional intelligence of teachers with the teaching experience of all the four categories was found to be similar.

\section{References}

5. Ahuja, B. (2006). Basic Principles of Education. Omega Publication, New Delhi.

6. Bhatnagar, R.P. (2008). Readings in Methodology of Research in Education. R. Lall Book Depot, Meerut.

7. Creswell, J.W. (2011). Educational Research: Planning Conducting, and Evaluating Quantitative and Qualitative Research. PHI Learning Private Limited, New Delhi.

8. Gupta, S.P. (2002). Modern Measurement and Evaluation. Sharda Pustak Bhawan, Allahabad.

9. Mishra, K.S. (1990). New Horizons of Education Psychology. Anubhav Publishing House, Allahabad211006.

10. Mangal, S.K. (2008). Education Psychology, Prantik Hall of India Private Limited. New Delhi.

11. Mathur, S.S. (2001). Education Psychology, Vinod Pustak Bhandar. Agra.

12. Sharma, R.A. (2002). Advanced Statistics in Education and Psychology. R. Lall Book Depot, Meerut.

13. Singh, M.K. (2000). Education and Society. Aditya Publishers, Beena (MP).

14. Sridhar (2007). Teacher Efficiency and Correlate of Primary School Teachers. Neelkamal Publications, Hyderabad, 7, 25-27. 